\title{
Challenging Dominant Representations of Marginalized Boys and Men in Critical Studies on Men and Masculinities
}

\author{
Steven Roberts and Karla Elliott
}

\begin{abstract}
Raewyn Connell famously theorized hegemonic masculinity, explaining its dominance over femininity and "subordinated" and "marginalized" masculinities. Attending to representations of the latter, we argue that "men in the margin" are commonly wrongly and/or simplistically depicted as regressive and violent in response to their marginalization. Focusing on representations of working-class boys and men, we illustrate the stereotypical treatment of "men in the margin" more broadly, making clear that this goes against Connell's treatment of such men. Conversely, privileged boys and men are commonly held up by critical studies on men and masculinities scholars as paragons of progressive change. The characterization of boys and men in the margin as regressive and patriarchal impedes the ability to address problems like violence, misogyny, and homophobia and overlooks the possibilities for transformation that emerge among marginalized communities.
\end{abstract}

Keywords: critical studies on men and masculinities, marginality, marginalized masculinity, masculinity, men in the margins, working-class men

The field of critical studies on men and masculinities (CSMM) is undergoing a reflexive moment. Tristan Bridges (2019), for instance, has appealed to CSMM researchers in the Global North to draw on work developed in subfields such as critical whiteness and heterosexuality studies. In the spirit of this thinking, we seek to problematize the ways much CSMM scholarship portrays and discusses men who have been considered under the categories of "marginalized" masculinities (Connell 1987, 2000, 2005), paying attention primarily to boys and men marginalized on the basis of their working-class position. While this call to greater reflexivity will necessarily produce discomfort, it is a longstanding and important issue with which the field of CSMM must grapple. 
We argue that CSMM scholarship about "men in the margin" (Elliott $2020 \mathrm{~b}$ ), such as working-class men and boys, men of color, and men with disability, often evidences ingrained "prenotions" (Durkheim 2014 [1895]). Will Atkinson (2019: 22) defines prenotions as "the everyday, practical understandings or constructs of the world which people have formed through experience to make sense of that experience, and that experience is, of course, differentiated by one's position in the social world." Though often motivated by social justice, much CSMM research consolidates the myth that men in the margin lag behind the real vanguard of progress: white, middle-class men. For brevity, we attend here to prenotions about, and dominant theorizing of, working-class boys and men's masculinity. Working-class boys and men are, of course, only one social group who might be considered in the margins: locked out of the power and privilege of hegemonic or complicit masculinities. Prenotions and stereotypes of other boys and men in the margins, including those with disability, men of color and queer people, result in similarly harmful positionings, and disparaging treatments of one marginalized group so often have implications for multiple groups of marginalized people.

The experience of many CSMM scholars will be having read about the explanatory power of menial wages, making ends meet, job loss and various stresses as drivers of toxic behaviors. Violence, sexism, and homophobia, then, are understood as working-class boys and men's response to powerlessness. James Messerschmidt (1993), for example, suggests that without a steady, reliable job (or the probability of obtaining one), or other traditional indicators of successful masculinity, violent behavior may establish legitimate routes to powerful manhood. However, concluding that working-class boys and men are more violent as a result of their conditions of existence-imbued with stress, precarity and inequality as they may be-is problematic and reflective of prenotions, rather than empirically or theoretically robust positions.

While largely unstated, implied in portrayals of boys and men in the margin as pursuing power through violence and misogyny is that privileged boys and men do not need to engage in such regressive tactics as they already hold power and privilege. This is somewhat insinuated, for example, in Sam de Boise's consideration that given their access to institutional power, "middle-class men, historically, have not necessarily been considered the most chauvinistic, homophobic, or 'physically' powerful" (de Boise 2015: 326). Such positions reify the masculinities of boys and men in the margin, locating these men as unchanging and pathological and overlooking some of the possibilities for transforming masculinities that emerge among those in the margins of society. Prenotions also hinder our ability to ad- 
equately address the causes of problems such as violence, misogyny, and homophobia. As Steven Roberts argues in relation to working-class young men, but with implications for broader groups in the margin: " $t]$ he widespread discursive construction of working-class masculinity as axiomatically 'in deficit' is an act of symbolic violence, but also functions as a diversionary tactic for middle-class and elite men whose practices are thus more rarely scrutinised. With working-class men positioned as the sole, or even main, bearers of 'bad' masculinity, attention to the oppression of women is only ever a limited enterprise" (2018: 216).

Given that "the dominant class have the power to impose their definitions of reality as legitimate" (Atkinson 2019: 23) —and academics are fundamental to the construction of such knowledge-our position is that we all must do more to move beyond explanations of working-class men based on prenotions. We argue that as part of CSMM's current reflexive moment, it is necessary to challenge the perpetuation of stereotypes of boys and men in the margin as more regressive than more privileged men. Part of this argument relies, as we have suggested elsewhere, on a consideration of "what counts as 'problematic' masculinity, and who gets to decide? What values are we bringing with us when we attempt to judge what men in our research should or should not be doing or saying?" (Elliott and Roberts 2020: 13).

We begin by highlighting Connell's sensitive treatment of working-class masculinity in The Men and the Boys (MATB), which avoided reification and the automatically negative portrayals that characterize many discussions of working-class boys and men. We then illustrate how CSMM often deviates from Connell's approach, instead often considering working-class boys and men as regressive and as seeking to compensate for lack of power and privilege through violence and domination. We trouble the idea, commonly advanced in the field, that privileged men are best situated to drive progress and transformation in masculinities. In closing, we suggest addressing these problems by turning to the growing body of research and theorizing from the margins. Such research challenges negative depictions of boys and men in the margins and suggests that an agenda for fairer representations must be advanced.

\section{Revisiting The Men and the Boys}

MATB brought together the trailblazing array of concepts and theorizing that Raewyn Connell had provided for the study of men and masculini- 
ties over the previous two decades: that masculinity is better understood as plural, and that masculinities are hierarchical and relational. Attending to power relations between genders and within genders, Connell illuminated the role and significance of hegemonic masculinity; this was "not necessarily what powerful men are, but what sustains their power and what large numbers of men are motivated to support" (Connell 1987: 185). Connell illustrated the politics within masculinity, that integral to the legitimization of hegemonic masculinity is the subordination and marginalization of other masculinities. Here gay men are represented through the concept of subordinated masculinities, with marginalized masculinities conceptualizing those that emerge from the interplay between gender and class and ethnic "Otherness." Buttressing the legitimacy of the hegemonic form, though, are complicit masculinities, performed by those men who benefit from hegemonic masculinity but do not necessarily enact it nor overtly endorse it.

Rather than attend to these much-discussed concepts and advances, we aim to revitalize Connell's agenda for the future of masculinities research as proposed in MATB. Containing six important directions, we train our focus to point five of this non-hierarchical list, which reads: "There is clearly a need to consolidate the analysis of masculinity in relation to class, race and ethnicity, and other issues of power" (Connell 2000: 26).

We contend that much CSMM scholarship has misunderstood, or been inattentive to, "the connections between the differences and hierarchies among men" that Connell (2000: 23) had in mind. Although Connell (2000: 23) made clear that "investigating the circumstances where gender patterns are less or more open to change seems an important task for research," in the 20 years since MATB, boys and men in the margin have rarely featured as potential agents of change. Instead, they have often been reduced to seeking power, dominance, and the continuation of oppressive gender relations. Connell (2000: 32) states "[m]en whose masculinities are formed around the continuing social subordination of women are likely to act in ways that sustain the patriarchal dividend." We suggest throughout this article that this has commonly been read as referring to men in the margin such as working-class men and men of color. However, in the next paragraph, Connell explains: “in certain situations men's relationships with particular women or children, or groups including women and children, define interests that are stronger than their shared interest as men. In all these ways men's general interest in patriarchy becomes incoherent or contestable (2000: 32)." Here, Connell highlights the potential for transformation and rejection of patriarchy among men in the margin as a result 
of their positionalities, starkly contrasting with the arguments that we explore that these men uphold patriarchy to compensate for lack of power. Connell's arguments here also echo Black feminist theorizing, which highlights that, while complex, solidarities and commonalities between men and women from marginalized groups are often greater than any based primarily on gender that might exist between middle-class white women and working-class Black women. Indeed, as bell hooks contends, "[ $t]$ here is a special tie binding people together who struggle collectively for liberation. Black women and men have been united by such ties" (2000: 70).

Connell's discussion in MATB of working-class boys and men in particular is sensitive and highly instructive, yet little replicated. Connell provides exemplary explorations of how working-class boyhoods are characterized by complex and varied experiences, somewhat complicating the dominant narrative of working-class boys as resistant to school. Instead, Connell explores boyhood as including commitments to processes of sexual and bodily exploration, of bodily shame, as well as the more conventional practices associated with masculinity such as valorizing sporting competitiveness.

In particular, though, Connell is sensitive to working-class men's marginality and experience of exploitation in capitalist societies, writing:

Cultural exclusion through inadequate education is only one of the ways a capitalist society erodes the self-confidence of working-class people. Disdainful treatment in hospitals, surveillance by welfare agencies, media hostility to strikes and community actions, and blocked promotion structures are all familiar experiences for them. The damaging relationship between educational authority and many working-class families parallels other interactions between working-class people and the state. Policing bears much more heavily on working-class people than on more privileged groups; a simple measure is the fact that the overwhelming majority of prisoners in gaols are working-class men. (Connell 2000: 106)

Connell furthermore provides an example of the potentials for transformation and progress among marginalized men through engaging with the issue of homophobia:

Many [working-class] parents did adjust to the news about their sons [being gay], some becoming quite supportive. The working-class family, despite heterosexual ideology, may be flexible enough in practice to embrace a male lover, not quite as a wife but still as part of the network (perhaps like a close family friend). Alongside religious bigotries and hypermasculinities, working-class traditions include a broad current of sexual explicitness ... and sexual tolerance. This can work to the advantage of homosexual men. Most of our respondents feel secure in their neighbourhoods, and some are "out" at work. Those who have suffered employment discrimination or aversion therapy were of course encountering the homophobia of employers and doctors, not the working class. We should not 
neglect the fact that class power means that the homophobia of the privileged impinges on working-class people. (Connell 2000: 110)

Rather than a picture of rampant prejudice on the part of working-class boys and men that sustains dominance, Connell here draws attention to the characteristics of this particularly marginalized community that pave the way for acceptance and even new, progressive forms of family arrangements. She also makes clear that homophobia encountered in this community stemmed largely from middle-class men. Despite this sophisticated nuance, dominant accounts in CSMM continue to perpetuate an idea that working-class boys and men are the bearers of "bad" masculinity (Ingram 2018; Roberts 2018). This, we argue, is contrary to Connell's theorization that patriarchy is perpetuated by powerful men who embody hegemonic masculinity or benefit from complicit masculinity.

\section{CSMM's Treatment of Working-Class Masculinities, Marginality, and the Pursuit of Power}

In this section we illuminate some ways the "working-class masculinity as deficit" discourse manifests and comes to influence the field. We provide several examples to offer an illustrative rather than exhaustive account, narrowing our attention to scholarship published after MATB. We first explore how this problem emerges in one prominent example: Bethany Coston and Michael Kimmel's (2012) well-cited article on "the intersectionality of privilege." We focus primarily on their treatment of working-class men, though their treatment of gay men and men with disability is similar, gesturing to our contention above that similar stereotypes are utilized in much research on all men in the margin. Next, we offer other examples that rely on prenotions to portray violence and dominance as predominantly the preserve of working-class men. We then turn to literature that, in a complementary mischaracterization, situates working-class boys and men as less progressive than middle-class men.

Coston and Kimmel (2012) argue that marginalization for men with disability, gay men and working-class men stems from being positioned as "not-men" or from being "emasculated." Taking emasculation as the basis of marginalization, Coston and Kimmel do not sufficiently attend to the marginalization that stems from, inter alia, economic deprivation; discrimination based on sexuality; and an environment of social and physical barriers for people with disability. Coston and Kimmel take an additive/subtractive 
approach to intersectionality — they focus on masculinity as the overarching category, plus or minus ability, sexuality or class. However, this approach to intersectionality underplays the complexities of how multiple axes of advantage or disadvantage interact.

Coston and Kimmel (2012: 110) combine this additive/subtractive approach with the assumption that the only course of action available to men in the margin in terms of masculinity is to grasp for greater power. Here, the marginalized become measured only through their relationship to, and envy of, more privileged groups. No space remains for the possibility that they might craft ways of life in their own right, or for the potentials for progress among marginalized groups highlighted by Connell above and explored further below.

For brevity, we outline just some of Coston and Kimmel's criticisms leveled against working-class men, though, as above their article contains many more discomforting prenotions about class, as well as men with disability and gay men. Primary for Coston and Kimmel is that the supposed emasculation of working-class men stems from their domination by managers and their societal positioning as "dumb." This leads to an all too familiar trope: these men attempt to recuperate a sense of status in their relationships with other working-class people through exercising power over them, seeing as they cannot do so with middle-class people. This assumption overlooks the longstanding working-class values of solidarity and community (Clark 1995), and repeated findings that working-class people routinely show more empathy, are more compassionate to those in distress, and give disproportionately to charity (e.g. Manstead 2018; Stellar et al. 2012). Indeed, this literature illuminates that lower-class individuals develop a "heightened awareness of how their environment shapes and constrains their behavior" (Stellar et al. 2012: 450). This problematizes Coston and Kimmel's suggestion that working-class men involved in unionism perpetuate the ideal of men as breadwinners and oppose the entry of all women and gay men into the workplace; a contention that also problematically overlooks the long history of working-class women's paid labor (Kessler-Harris 2003 [1982]). Coston and Kimmel even state outright that for working-class men, "sexism and patriarchy are key features of their masculine dominance" (2012: $108)$ and " $[t]$ here is a type of White, male, working-class solidarity vis-à-vis privilege that these men have constructed and maintained, that promotes and perpetuates racism, sexism, and homophobia" (2012: 109).

Coston and Kimmel furthermore perpetuate the idea that working-class men are more violent in public because of their marginalization, and finally 
that these violent dispositions filter into the home. Distressingly, Coston and Kimmel (2012: 109) claim "[i]n the absence of legitimated hierarchical benefits and status, working-class husbands and partners are more likely to 'produce hypermasculinity by relying on blatant, brutal, and relentless power strategies in their marriages, including spousal abuse' (Pyke 1996).” This position relies on the prenotion that the working-class other is more violent; yet, whether lower socioeconomic status and lower education levels increase the probability or frequency of violence against women is disputed, with studies finding mixed results (Our Watch, ANROWS and VicHealth 2015). For certain, though, intimate partner and family violence is perpetrated across class divides (Phipps 2009).

Without a nuanced analysis of masculinity and marginality, a variety of scholarship continues similarly with the prenotion of working-class men's violence. A somewhat telling contribution is Peter Jansson's summation:

In a society that offers high possibilities for men doing masculinity with conventional means, men with high access to economic, social and cultural resources of doing masculinity will naturally strive to distance themselves from [violence against women] as part of their masculinity construction. In a society that offers low possibilities for men doing masculinity with conventional means and where men have low access to economic, social and cultural resources, [violence against women] presents one of the few ways for men to reinforce their masculinity. (2017: 3)

The "prenotional" association of working-class boys and men with greater violence against women persists with little to no reflection on how or why, as above, middle-class men engage in such acts of violence at the same rate, and do so with impunity in the case of - among others-the current US president (at the time of writing). The relatively much smaller literature that "studies up" in a way that problematizes middle-class masculinity is important but has not yet shifted the dial (e.g. Donaldson and Poynting 2007; Elliott 2020a).

Following the "tendency to use working-class identity as a repository for anti-social attitudes and attributes" (Walker \& Roberts 2018: 3), Andy Hochstetler, Heith Copes, and Craig Forsyth also draw on the prenotion of working-class men's violence with a focus on those who participate in bar fights. They argue that "specific elements of fighting events represent symbolic attempts at attaining and maintaining honor and status, which many men in working-class culture equate with masculine identity" (2014: 493), despite honor and status being valued traits of masculinity across the class spectrum. Again as with many other scholars, these authors' position is underpinned by the assumption that "pursuit of symbolic masculinity 
is important to working-class men, who possess fewer alternative avenues for achieving status than do those from higher social ranks" (Hochstetler et al. 2014: 493).

This idea is present in various international contexts. Christian GroesGreen (2009), writing about Maputo, Mozambique, suggests that young working-class men react to poverty and unemployment with violence against women or sexual performance with women partners in order to gain authority, while middle-class men maintain their power through breadwinner ideology and financial status. Groes-Green bases this argument on the fact that more working-class than middle-class young men in his focus group discussions claimed to be violent toward women. These judgments are made on a sample of 69 working-class young people and just 21 middle-class young people. This parallels a similar issue in work by Raquel Sukhu (2013) that, while making commendable efforts to understand and prevent Trinidadian men's violence against women, finds violence is integral to working-class men's masculine gender identity. Situating class as an independent variable here is not possible when the sample is made up of only or mainly working-class men.

Moreover, Groes-Green's account relies on a partial reading of Connell's notion of "protest masculinity," in short the idea of "making a claim to power where there are no real resources for power" (Connell 2005: 111). Rather than arguing that "poverty and marginalization of a social class tend to increase the use of violence and coercion" (Groes-Green 2009: 289), Connell's analysis of working-class and unemployed men's life histories was more nuanced. Indeed, Connell (2005: 110) made clear that protest masculinity involved a variety of gender practices including "violence, school resistance, minor crime, heavy drug/alcohol use, occasional manual labor, motorbikes or cars, short heterosexual liaisons." The issue of the variety of options other than violence as a route towards protest is matched in importance by the oft-overlooked issue of exaggeration (see Connell 2005: 110112). Connell (2005) is clear that protest masculinity is a facade, that it is "showy" (2005: 110), about keeping face and putting "up a front" (2005: 111). The fact that the stories of violence in Groes-Green's focus groups are likely to be, at least in part, discursive constructions of masculinity of this kind gets no attention. Nor does the prospect that middle-class men understand how to adhere to "spoken egalitarianism," which does not automatically equal egalitarianism in practice (Roberts 2018). Of equal significance, Groes-Green, like others, overlooks that protest masculinity "is not simply observance of a stereotyped male role. It is compatible with respect 
and attention to women ... egalitarian views about the sexes ... affection for children ... and a sense of display which in conventional role terms is decidedly feminine" (Connell 2005: 112). To be clear, we do not deny that boys and men in the margin engage in harmful behaviors. Rather, we point to how taken-for-granted discourses about these men draw attention away from the harmful practices among more privileged men and are based on assumptions that men in the margin only ever want a share in the power of their more privileged counterparts. This leaves no room for resistance or change among men in the margin, with privileged men thus automatically positioned as the harbingers of progress.

\section{The Positioning of Privileged Men as the Source of Productive Change}

Situating men in the margin as regressive, violent, and always maintaining inequalities results in more privileged men being positioned as those leading progress in terms of masculinities. This has become particularly visible more recently with the theorization of "caring masculinities" (Elliott 2016) and the growth of research on fathering. While much of this work on fathering is unproblematic, a notable amount locates middle- and upper-class men as mostly or even solely capable of positive change and transformation in terms of men's caring. Indicative here is recent work by Sarah Hunter, Damien Riggs, and Martha Augoustinos (2017: 6). Couching their arguments in a critical discussion of how the "new fatherhood" might be an expansion of hegemonic masculinity, these authors have suggested that the emergence of "new and involved fatherhood is very much associated primarily with White, middle-to-upper class fathers.” They state that such fathers "possess the economic, social, and cultural resources to be able to take risks with their masculine identities." Based on their assessment of the literature on white, middle-to-upper class fathers, Hunter and colleagues conclude that "masculinity is not evolving or changing per se but rather ... those who meet current norms and expectations of hegemonic masculinity are afforded the luxury to be involved in caregiving" (2017: 6).

Although advocating for researchers to adopt a class analysis in studies of fatherhood, Hunter and colleagues position men's caregiving as the purview of the privileged, overlooking the literature that has long documented working-class men's significant involvement in care work for, for example, children (e.g. Lawson 1995; Rudd and Root 2008). As just one example, Helene Lawson (1995) found that working-class participants in her research "were not bound by traditional rigid gender roles, nor did they 
aspire to or value them. Rather, manual working-class wives ... wanted equality and careers. Their husbands were often open to change and enjoyed a lifestyle which brought them closer to their children." This parallels Connell (2005: 118), who highlighted the "economic logic of [workingclass men's lives] that underpins egalitarian households, the personal experience of women's strength, and the interest that several of the men [in the study] have in children."

Hunter and colleagues do refer in passing to Mario Liong's (2017) work, which finds more sustained nurturing and caring identities among working-class fathers in Hong Kong compared to middle-to-upper class fathers. This becomes subsumed, however, in Hunter and colleagues' assertion that it is privileged men who are able to take up caring roles as part of their strategies of maintaining power and privilege, with care removed here from working-class men's lives entirely. Hunter and colleagues do highlight, though, that privileged men are more rewarded and valorized for taking on caring roles than working-class men, and that privileged men can maintain their access to power and privilege despite taking on these roles (or, Hunter and colleagues argue, as part of taking on these roles). Accordingly, Hunter and colleagues do productively problematize forms of caring among middle- and upper-class men. However, they simultaneously reduce the enactment of care in the lives of working-class men, thereby positioning middleor upper-class men as those among whom change is taking place, even if that change needs to be problematized.

Such thinking is reflected in scholarship more broadly. Returning to Coston and Kimmel (2012), they argue that middle-class men take on accountability and responsibility as role models to their sons, as opposed to working-class men who, these authors claim, place the onus of responsibility to grow up well onto their sons. Meanwhile, Marci Cottingham (2017: 272), considering men's development of more emotional repertoires, contends that "[r]edefinitions of masculinity toward a more sensitive ideal might come from those privileged by other social characteristics such as race, socioeconomic status, and sexuality." Furthermore, critiquing inclusive masculinity theory, de Boise (2015: 326) wonders whether the more progressive behaviors underpinning Eric Anderson's (2009) findings "may ... only be describing the behavior of the "sexually liberal," complicit, and middle classes." This reticence to situate working-class men as capable of social progress also seemingly underpins Jeff Hearn's (2020) concern that such men's accounts might mistakenly be taken at "face value." 
The positioning of more privileged men as the vanguard of progress and change is much advanced in CSMM even though violence, sexism, and homophobia are carried out by privileged men with power, too. Privileged men are, though, less often held to account for these behaviors (Phipps 2009). War constitutes one of the most obvious examples of violence organized and initiated by powerful, privileged men, who enlist men in the margin to carry it out. These same, less privileged men are all too often presumed to be the primary perpetrators of rape and sexual violence, despite studies finding little to no evidence that perpetrators of sexual assault come from any one social class (Murdolo and Quiazon 2016; Phipps 2009). What does happen is that working-class and ethnic minority or Indigenous men are more likely to be arrested, charged, and convicted (Phipps 2009). In fact, the argument in the kinds of literature explored above is that men in the margin enact regressive behaviors because of a lack of power. Yet this argument is contradicted by the fact that privileged men with power also carry out these problematic behaviors. Thus, the argument that privileged men are better situated to enact change is at best paradoxical: if gaining power is key for men (as many authors claim it is, though this could be questioned, too), why would privileged men give up their power to enact change for those with less power?

\section{Conclusion: Looking to the Margins for How to Represent the Marginalized}

As above, depictions of working-class masculinity in CSMM are often homogeneous, static, and reductive. Through the projection of negative value, working-class boys and men are situated as unable to shake off the stigma of being regressive, as "not as good as the middle class." Such accounts are imbued with somewhat subtle, seemingly palatable versions of class-based disgust (Tyler 2008), where "the unruly, uncivilised, violent working-class Other is a repository for the qualities middle-class cultures fear and appear to reject" (Phipps 2009: 670).

Against CSMM's hegemonic reading of working-class masculinity, an increasing number of authors disrupt this seemingly "common sense" interpretation, and often these authors are themselves from the marginsincluding working-class and queer scholars and scholars of color. We must turn to and learn from those in the margins in order to move away from stereotypes and prenotions, which restrict our ability to understand both discrimination and power, and pathways to change. Nicola Ingram 
(2018), for example, building on Diane Reay's (2002) single-person case study, sympathetically portrays working-class boys' negotiation of educational success in Belfast. Meanwhile, Michael Ward (2015) captures the diversity of working-class dispositions in his nuanced account of teenage boys' "doing" masculinity in the South Wales valleys. Further, Roberts' (2018) longitudinal study of young working-class men in South-East England highlights a positive embrace of traditionally "feminized" employment and a commitment to fairer distribution of household labor. The latter somewhat replicates findings in studies that illustrate that white-collar middle-class men engage in discursive tactics of spoken egalitarianism, but that working-class men go quietly about the practice of more egalitarian domestic arrangements (Lyonette and Crompton 2015; Sullivan 2010; see also Behnke and Scholz 2015).

Social class is of course only one dimension of potential marginality; a related emerging scholarship extends the same critical challenge to hegemonic readings of other men in the margins. This scholarship highlights possibilities for productive change among men in the margins, and underscores that dispensing with stereotypes is key for achieving social justice. Cornelia Behnke and Sylka Scholz (2015), for instance, find that East German men today have egalitarian, pragmatic partnership arrangements, rather than simply subscribing to the West German discourse of involved fatherhood. Behnke and Scholz note that these more egalitarian arrangements are undramatic and unsensational, and thus do not receive the attention afforded to discourses of involved fatherhood among privileged men. Similarly, Santokh Singh Gill (2018) challenges stereotypes of British South Asian men as deviant, patriarchal, effeminate, or hyper-masculine, instead finding that care for children and obligations and desires to care for parents and family members are key features of such men's lives.

These more positive accounts of men in the margins follow the principles of analyses of power in Black feminist thought, and also in scholarship about men and masculinity from post-colonial contexts. In both cases, there is a history of understanding men as both oppressors and oppressed, and a line of reasoning that questions the construction of knowledge that features in the hegemonic Global North. While maintaining that sexism "can only be successfully eradicated if men are compelled to assume responsibility for transforming their consciousness" (hooks 2000: 83), Black feminists have suggested that the "assumed privileged gender position of men in the context of people of color is not always accurate" (Mutua 2013: 347), and as above have noted the shared solidarities between people of 
different genders in marginalized communities. hooks (2000: 70) reveals the possibilities for change stemming from the "special tie binding people together who struggle collectively for liberation," noting in particular the political solidarity between Black women and men, "the experience of shared resistance struggle," and the "positive experiences [of] working with men politically" available to women in the margins that tend not to be available to bourgeois white women.

Post-colonial literature also complicates the universality of men's power and privilege. While care must be taken to not jump on the "decolonial bandwagon" (Moosavi 2020), such work provides more fine-grained examples for how men in the margins can be discussed beyond their assumed quest for power. In such literatures, for example, the structuring effects of neoliberal development upon the possibilities for and directions of masculinities are foregrounded, rather than particular actions of specific men. For instance, Connell (2016) points to Silberschmidt's (2004) study of HIV transmission in East Africa to explain that men's assertion of sexual privilege is an artifact of how colonialism and post-colonial economic change ruptured and re-created the gender order. Others, such as Dominic Pasura and Anastasia Christou, have pushed back against academic studies that prop up reductive and frankly racist tropes of blackness and hypersexuality and render African masculinities "immutable, violent, patriarchal, and oppressive" (2018: 254). Post-colonial scholarship has also illustrated that breadwinner masculinity — and feminine domesticity—was a colonial export (Mbah 2019), and that it was colonial societies that "undermined non-patriarchal hegemonic masculinities" that had existed in pre-colonial matrilineal societies (Uchendu 2008: 13). More positive accounts of masculinity emerge, too, that challenge the prenotions that permeate Western understandings of the universally problematic ethnic "Other." For example, Luisa Dietrich Ortega's (2012) research of Latin American guerrilla movements documents variability in practices of masculinity in these movements and "a significant place for emotion, and an ideology of social equality that often gave women a prominent role" (Connell 2016: 308).

The more sensitive accounts of men in the margin offered by scholars in the margins themselves, explored briefly here, move away from stereotypes and prenotions to offer more nuanced, useful considerations of men, masculinity and marginality, as Connell did, too, in MATB. The work of scholars in the margins presents opportunities to more critically engage with the positioning of middle-class men in the West as the bastions of progress and virtue and can facilitate moving away from setting up the more privileged 
in society_-including researchers of men and masculinities-as those from whom everyone else ought to learn. Turning to and learning from those in the margins can also illuminate the potentials for progress and change that stem from the margins.

Steve Roberts is Associate Professor of Sociology in the School of Social Sciences, Monash University, Australia. His research interests revolve around youth, masculinity and social change. Steve's recent books include Young Working-Class Men in Transition (Routledge) and Masculinity, Labour and Neoliberalism (Palgrave; co-edited with Charlie Walker). Steve is mixed race Indian/White British, and was brought up in a white, working-class mining community by a White, unemployed, single mother. Both are survivors of and witnesses to systematic brutalisation enacted by violent men who passed through their lives. Steve was, and remains, the first member of his family to complete a university degree. ORCID: https:// orcid.org/0000-0003-4000-2257. Email: steven.d.roberts@monash.edu

Karla Elliott is a Lecturer in Sociology in the School of Social Sciences at Monash University, Australia. Her research explores men, masculinities, gender, social inequalities, and possibilities for change. She has also published on family violence and on narrative research methods. She is author of the book Young Men Navigating Contemporary Masculinities (Palgrave) and has received funding for her research from the Australian Research Council and The Victorian Health Promotion Foundation. ORCID: https://orcid.org/0000-0002-8985-4533 Email: karla. elliott@monash.edu

\section{References}

Anderson, Eric. 2009. Inclusive Masculinity. New York: Routledge. Atkinson, Will. 2019. Bourdieu and After. London: Routledge.

Behnke, Cornelia, and Scholz, Sylka. 2015. "Ambivalenzen und Spezifika in ostdeutschen Paar-Arrangements und väterlichen Praxen." ["Ambivalences and Specifics in East German Pair-Arrangements and Fatherhood Practices."] In Männlichkeit und Reproduktion: zum gesellschaftlichen Ort historischer und aktueller Männlichkeitsproduktionen, [Masculinity and Reproduction: The Social Location of Historical and Current Productions of Masculinity] ed. Andreas Heilmann, Gabriele Jähnert, Falko Schnicke, Charlott Schönwetter, and Mascha Vollhardt, 155-174. Wiesbaden: Springer. 
Bridges, Tristan. 2019. "The Costs of Exclusionary Practices in Masculinities Studies." Men and Masculinities 22 (1): 16-33.

Clark, Anna. 1995. The Struggle for the Breeches: Gender and the Making of the British Working Class. Berkeley: University of California Press.

Connell, Raewyn. 1987. Gender and Power. Stanford, CA: Stanford University Press.

Connell, Raewyn. 2000. The Men and the Boys. Sydney: Allen \& Unwin.

Connell, Raewyn. 2005. Masculinities. Berkeley: University of California Press.

Connell, Raewyn. 2016. "Masculinities in Global Perspective: Hegemony, Contestation, and Changing Structures of Power." Theory and Society 45 (4): 303-318.

Coston, Bethany, and Michael Kimmel. 2012. "Seeing Privilege Where It Isn't: Marginalized Masculinities and the Intersectionality of Privilege." Journal of Social Issues 68 (1): 97-111.

Cottingham, Marci. 2017. "Caring Moments and Their Men: Masculine Emotion Practice in Nursing." NORMA 12 (3-4): 270-285.

de Boise, Sam. 2015. "I'm Not Homophobic, I've Got Gay Friends': Evaluating the Validity of Inclusive Masculinity." Men and Masculinities 18 (3): 318-339.

Dietrich Ortega, Luisa. 2012. "Looking Beyond Violent Militarized Masculinities: Guerrilla Gender Regimes in Latin America." International Feminist Journal of Politics 14 (4): 489-507.

Donaldson, Mike, and Scott Poynting. 2007. Ruling Class Men: Money, Sex, Power. Sydney: Peter Lang.

Durkheim, Emile. 2014. The Rules of Sociological Method. New York: The Free Press.

Elliott, Karla. 2016. "Caring Masculinities: Theorizing an Emerging Concept." Men and Masculinities 19 (3): 240-259.

Elliott, Karla. 2020a. Young Men Navigating Contemporary Masculinities. Cham: Palgrave.

Elliott, Karla. 2020b. "Bringing in Margin and Centre: 'Open' and 'Closed' as Concepts for Considering Men and Masculinities." Gender, Place \& Culture. doi:10.1080/0966369X.2020.1715348

Elliott, Karla, and Steven Roberts. 2020. "Balancing Generosity and Critique: Reflections on Interviewing Young Men and Implications for Research Methodologies and Ethics." Qualitative Research. doi:10.1177/1468794120904881.

Gill, Santokh Singh. 2020. “II Need to Be There': British South Asian Men's Experiences of Care and Caring." Community, Work \& Family 23 (3): 270-285. Groes-Green, Christian. 2009. "Hegemonic and Subordinated Masculinities: Class, Violence and Sexual Performance among Young Mozambican Men." Nordic Journal of African studies 18 (4): 286-304. 
Hearn, Jeff. 2020. "Book Review: Steven Roberts, Young Working-Class Men in Transition.” Sociology 54 (1): 202-204.

Hochstetler, Andy, Heith Copes, and Craig Forsyth. 2014. "The Fight: Symbolic Expression and Validation of Masculinity in Working Class Tavern Culture." American Journal of Criminal Justice 39(3): 493-510.

Hunter, Sarah, Damien Riggs, and Martha Augoustinos. 2017. "Hegemonic Masculinity versus a Caring Masculinity: Implications for Understanding Primary Caregiving Fathers." Social and Personality Psychology Compass 11 (3): e12307.

hooks, bell. 2000. Feminist Theory: From Margin to Center. London: Pluto Press. Ingram, Nicola. 2018. Working-class Boys and Educational Success. London: Palgrave.

Jansson, Peter. 2017. "An Explorative Integration of Factors Causing Men's Violence against Women." Journal of Psychology and Clinical Psychiatry 8 (2): 2-11.

Kessler-Harris, Alice. 2003. Out to Work: A History of Wage-earning Women in the United States. New York: Oxford University Press.

Lawson, Helene. 1995. "Gender Equality in the Manual Working Class." Race, Gender \& Class 2 (2): 127-138.

Liong, Mario. 2017. "Sacrifice for the Family: Representation and Practice of Stay-at-home Fathers in the Intersection of Masculinity and Class in Hong Kong." Journal of Gender Studies 26 (4): 402-417.

Lyonette, Claire, and Rosemary Crompton. 2015. "Sharing the Load? Partners' Relative Earnings and the Division of Domestic Labour." Work, Employment and Society 29 (1): 23-40.

Manstead, Antony. 2018. "The Psychology of Social Class: How Socioeconomic Status Impacts Thought, Feelings, and Behaviour." British Journal of Social Psychology 57(2): 267-291.

Messerschmidt, James. 1993. Masculinities and Crime. New York: Rowan \& Littlefield.

Mbah, Ndubueze. 2019. Emergent Masculinities: Gendered Power and Social Change in the Biafran Atlantic Age. Athens: Ohio University Press.

Moosavi, Leon, 2020. "The Decolonial Bandwagon and the Dangers of Intellectual Decolonisation." International Review of Sociology, 1-23. doi.org/ 10.1080/03906701.2020.1776919

Murdolo, Adele, and Regina Quiazon. 2016. Key Issues in Working with Men from Immigrant and Refugee Communities in Preventing Violence against Women. Sydney: White Ribbon Australia.

Mutua, Athena. 2013. "Multidimensionality Is to Masculinities What Intersectionality Is to Feminism.” Nevada Law Journal 13: 341-367. 
Our Watch, ANROWS and VicHealth. 2015. Change the Story: A Shared Framework for the Primary Prevention of Violence against Women and their Children in Australia. Melbourne: Our Watch.

Pasura, Dominic, and Anastasia Christou. 2018. "Theorizing Black (African) Transnational Masculinities." Men and Masculinities 21 (4): 521-546.

Phipps, Alison. 2009. "Rape and Respectability: Ideas about Sexual Violence and Social Class.” Sociology 43(4): 667-683.

Pyke, Karen. 1996. "Class-based Masculinities: The Interdependence of Gender, Class, and Interpersonal Power." Gender \& Society 10 (5): 527-549.

Reay, Diane. 2002. "Shaun's Story: Troubling Discourses of White WorkingClass Masculinities." Gender and Education 14 (3): 221-234.

Roberts, Steven. 2018. Young Working Class Men in Transition. London: Routledge.

Rudd, Elizabeth, and Lawrence S. Root. 2008. "We Pass the Baby off at the Factory Gates': Work and Family in the Manufacturing Midwest." In The Changing Landscape of Work and Family in the American Middle Class: Reports from the Field, ed. Elizabeth Rudd and L. Descartes, 61-85. Plymouth: Lexington Books.

Silberschmidt, Margarethe. 2004. "Masculinities, Sexuality and Socio-economic Change in Rural and Urban East Africa." In Re-thinking Sexualities in Africa, ed. Signe Arnfred, 233-248. Uppsala: Nordiska Afrikaininstitutet.

Sukhu, Raquel. 2013. “Masculinity and Men's Violence against Known Women in Trinidad-Whose Responsibility?" Men and Masculinities 16 (1): 71-92.

Sullivan, Oriel. (2010). Changing Differences by Educational Attainment in Fathers' Domestic Labour and Child Care. Sociology, 44 (4), 716-733.

Stellar, Jennifer, Vida Manzo, Michael Kraus, and Dacher Keltner. 2012. "Class and Compassion: Socioeconomic Factors Predict Responses to Suffering." Emotion 12 (3): 449-459.

Tyler, Imogen. 2008. “'Chav Mum Chav Scum': Class Disgust in Contemporary Britain. Feminist Media Studies 8 (1): 17-34.

Uchendu, Egodi. 2008. "Introduction: Are African Males Men? Sketching African Masculinities." In Masculinities in Contemporary Africa, ed. Egodi Uchendu, 1-17. Dakar: CODESRIA.

Ward, Michael. 2015. From Labouring to Learning, Working-class Masculinity, Education and De-industrialization, Basingstoke: Palgrave.

Walker, Charles, and Steven Roberts. 2018. Masculinity, Labour, and Neoliberalism: Working-Class Men in International Perspective. Palgrave: London. 